\title{
SOLVING THE ALLY-VERSUS-ACQUIRE DILEMMA THROUGH THE DUAL LENSES OF SUBJECTIVE AND OBJECTIVE VIEWS
}

\author{
Chiung-Hui TSENG \\ Institute of International Business, College of Management, \\ National Cheng Kung University 1, Ta-Hsueh Road, Tainan 701, Taiwan \\ E-mail: ctseng@mail.ncku.edu.tw
}

Received 19 August 2016; accepted 24 March 2017

\begin{abstract}
Nowadays many firms seek hard-to-imitate assets via allying with or acquiring other firms that own desired resources. As such, how to choose between alliances and acquisitions becomes a critical decision, and one important determinant is interfirm factors. This study probes three crucial yet underexplored interfirm differences, and develops scales to capture managers' perceptions of the differences that, based on managerial cognition literature, dictate the ally-versus-acquire choice. Further, we argue that managers adjust their judgement across varying objective conditions. Each perceived difference is thus paired with a moderator identified respectively from the resource-based view, competitive dynamics, and collaborative capability literature. Evidences on Taiwanese firms show that a larger resource-deployment difference enhances acquisition likelihood, while greater differences in marketing praxis and human resource management increase alliance formation. Moreover, the resource-deployment difference leads to alliances for relatively younger partners, and the difference in human resource management favors acquisitions when focal firms have more interfirm governance experience.
\end{abstract}

Keywords: ally-versus-acquire decision, governance mode choice, alliance, acquisition, interfirm difference, subjective assessment, objective condition.

JEL Classification: L10, L20, L21, L24, L60, M10, O53, P13.

\section{Introduction}

Alliances and acquisitions are vehicles through which firms access hard-to-imitate assets owned by others (Cuypers et al. 2017; Wassmer et al. 2017). Although both practices entail interfirm interaction and coordination, alliances (whether equity- or nonequity-based) are exercised by cooperation between firms that maintain their independent identities and ownerships (Lioukas et al. 2016; Reuer, Devarakonda 2016), while acquisitions are executed via internalization in which a target firm surrenders its ownership and control to the acquirer (Glendening et al. 2016; Graffin et al. 2016). These two governance modes have distinct advantages and disadvantages. It is thus important for firms to understand when to choose one over the other. One determinant long recognized in the literature is interfirm differences, and previous research tends to 
rely heavily on objective proxies to capture the differences (Wang, Zajac 2007; Yang et al. 2010).

Though insightful, there are limitations to assess interfirm differences using objective measures. First, objective indicators do not reflect managers' cognitive interpretations and diagnoses of other firms. As the managerial cognition literature suggests, firms' strategic choices are shaped largely by how top executives conceive and diagnose their competitive environments (Ginsberg 1994). Second, recent research (Bauer, Matzler 2014) shows that managers consider both subjective evaluations and objective information simultaneously. A disconnection between subjective and objective assessments prevents us from developing a finer-grained explanation for the ally-versus-acquire decision.

This research aims to address the above gaps by asking: How do perceptions of interfirm differences affect the choice between alliances and acquisitions, and how are these influences contingent on hard-fact conditions? Our study makes at least three important contributions. First, we expand the interfirm-difference discussion to three critical organizational routines (deploying resources, exercising marketing praxes, and managing employees) that need more investigation as Lavie et al. (2012) suggested. These underexplored interfirm differences deserve attention in the ally-versus-acquire decision because firms use either strategy to achieve resource-, market-, and efficiencyseeking goals. Second, this study is the first to capture managers' assessment of those interfirm differences that, according to the managerial cognition literature, determines the governance mode choice. Third, we contribute by analyzing how these interfirm differences interact with objective conditions (firm age, industry sectors, and interfirm experience) to impact the ally-versus-acquire preference. Our argument can be extended to other strategic settings, such as foreign market entry, which have long perplexed managers and scholars.

In the following sections we compare alliances and acquisitions, and develop our conceptual framework. Next, we describe methods. Then, we report results, followed by conclusions that state contributions and suggest future directions.

\section{Literature and hypotheses}

Alliances and acquisitions have their own advantages and disadvantages (please see Table 1 for a comparison). To decide between them, firms ought to weigh which strategy could bring more benefits than drawbacks under various conditions. In relation to this, managers develop and use their mental models to make decisions. A mental model is a managerial perception reflecting a "knowledge framework that selects and actively modifies experience in order to arrive at a coherent, unified, expectation-confirming and knowledge-consistent representation of an experience" (Alba, Hasher 1983: 203). However, managers' cognitive assessments likely reflect an incomplete picture in complex information environments. Likewise, using only objective data and overlooking managers' knowledge of a subject is problematic. There is thus a need to examine simultaneously the subjective and objective scanning of internal and external information for the ally-versus-acquire choice. 
Table 1. Comparison of key characteristics between alliances and acquisitions

\begin{tabular}{|c|c|c|}
\hline Features & Alliance & Acquisition \\
\hline Definition & $\begin{array}{l}\text { A voluntary agreement between firms } \\
\text { that share resources for co-development } \\
\text { or co-provision of products and } \\
\text { services }\end{array}$ & $\begin{array}{l}\text { A corporate action in which one firm } \\
\text { buys the ownership stakes of a target } \\
\text { firm in order to assume control of the } \\
\text { target firm }\end{array}$ \\
\hline Practice & $\begin{array}{l}\text { Exercised by cooperation between firms } \\
\text { that maintain independent identities and } \\
\text { ownership }\end{array}$ & $\begin{array}{l}\text { Executed via internalization where a } \\
\text { target firm surrenders its control and } \\
\text { ownership to the acquirer }\end{array}$ \\
\hline Coordination & $\begin{array}{l}\text { Coordination is sustained by discrete } \\
\text { negotiations and mutual expectations of } \\
\text { reciprocity }\end{array}$ & $\begin{array}{l}\text { Coordination is sustained mostly through } \\
\text { managerial fiat within the hierarchy }\end{array}$ \\
\hline Flexibility & $\begin{array}{l}\text { More flexible in that allying firms } \\
\text { can adjust the form of partnerships to } \\
\text { respond to unexpected changes }\end{array}$ & $\begin{array}{l}\text { Riskier and less flexible due to a } \\
\text { significant, irreversible financial payment } \\
\text { for completing the deal }\end{array}$ \\
\hline $\begin{array}{l}\text { Control over } \\
\text { desired assets }\end{array}$ & $\begin{array}{l}\text { Absence of formal managerial fiat does } \\
\text { not guarantee full control over the } \\
\text { desired assets possessed by partners }\end{array}$ & $\begin{array}{l}\text { Being under a common ownership and } \\
\text { managerial authority gives the acquirer a } \\
\text { better control over the desired assets of } \\
\text { the target }\end{array}$ \\
\hline $\begin{array}{l}\text { Asset } \\
\text { indigestibility }\end{array}$ & $\begin{array}{l}\text { Less severe as allying firms can } \\
\text { cooperate only in the areas that are } \\
\text { mutually beneficial }\end{array}$ & $\begin{array}{l}\text { More severe as an acquisition often } \\
\text { commingles with the unwanted assets of } \\
\text { the target }\end{array}$ \\
\hline $\begin{array}{l}\text { Transactional } \\
\text { hazard }\end{array}$ & $\begin{array}{l}\text { Incomplete contracts brought by } \\
\text { bounded rationality likely expose } \\
\text { allying firms to threats of partners' } \\
\text { opportunism, such as hold-up, leakage } \\
\text { of know-how, and so on }\end{array}$ & $\begin{array}{l}\text { Information asymmetry between the } \\
\text { acquirer and the target likely leads to } \\
\text { adverse selection, as the acquirer cannot } \\
\text { ascertain the true value of the target }\end{array}$ \\
\hline $\begin{array}{l}\text { Managerial } \\
\text { challenge }\end{array}$ & $\begin{array}{l}\text { Lack of a common control system } \\
\text { and laying governance scheme on } \\
\text { incomplete contracts are harmful to } \\
\text { solving conflicts }\end{array}$ & $\begin{array}{l}\text { Integration of the acquirer and the } \\
\text { target under a common ownership } \\
\text { and managerial authority is costly and } \\
\text { complex }\end{array}$ \\
\hline
\end{tabular}

We identify three critical organizational routines, and argue that the effects of the three perceived interfirm differences are moderated by respective objective conditions. According to the resource-based view, resource-deployment differences represent each firm's unique trajectories of competency development, and firm age is a crucial objective indicator that hints at the logic of a firm's resource allocation to outsiders (Wernerfelt 1984; Winter 2003). Marketing-praxis differences allude to potential competitive relationships, and this competitive intensity differs between high- and low-tech segment (Czarnitzki, Thorwarth 2012; Hagedoorn, Duysters 2002). The differences in human resource management denote managerial challenges facing alliance or acquisition participants, and their prior interfirm governance experience (known as collaboration capability) affects how they tackle the managerial difficulties (Ellis et al. 2011; Madsen, Desai 2010). Figure 1 illustrates our conceptual framework. 


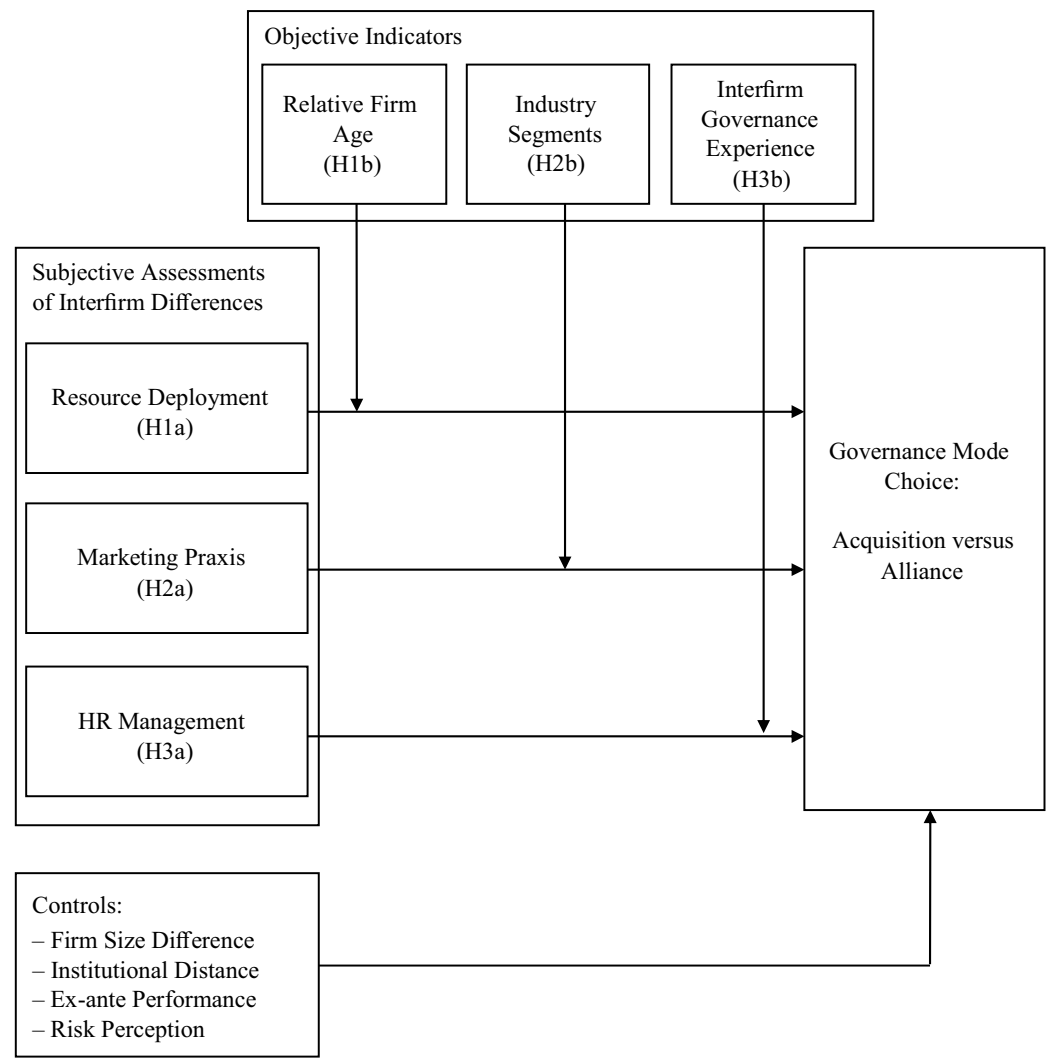

Fig. 1. The conceptual framework

\subsection{Resource deployment and relative firm age}

\subsubsection{Effects of perceived differences in resource deployment}

Resource deployment refers to the commitment of resources to specific areas that are converted into rent-generating capabilities over time (Kor, Mahoney 2005). According to the resource-based view, resource deployment dictates what capabilities firms are equipped with, and the capabilities are often not perfectly mobile and imitable across firms (Barney 1991). A large difference in resource deployment between firms suggests that these firms are more likely to possess knowledge and competencies substantially divergent from each other. In this case, an acquisition becomes a better vehicle than an alliance for firms aiming to obtain the knowledge and/or capabilities held by others.

First, because of disparate trajectories of resource deployment between two firms, it is difficult for a focal firm, as an outsider, to make sense of how another firm uses its resources. Becoming an insider via acquisitions can overcome this causal ambiguity. Second, although acquirers may confront challenges in gauging targets' competency value and assimilating knowledge when there is a large interfirm resource-deployment difference (Carayannopoulos, Auster 2010), alliances also expose participants to similar 
types of risks, including poor partner selection and low absorptive capacity (Fonti et al. 2017; Holloway, Parmigiani 2016).

Taken together, because of resource inimitability and immobility in the situation of greater resource-deployment differences, an acquisition is a more feasible mode than an alliance for a focal firm to obtain the desired knowledge and competencies while maintaining the value embedded in the target company.

H1a: Other things being equal, a greater perceived interfirm difference in resource deployment is associated with the choice of an acquisition over an alliance.

\subsubsection{Moderation of relative firm age}

Stressing idiosyncratic paths of organizational growth across firms, the resourcebased view (Wernerfelt 1984) and the capability perspective (Winter 2003) have long implied the crucial role of firm age in the deployment of resources and development of capabilities.

Focal firms facing younger candidates prefer alliances, as the concerns about asset immobility and inimitability brought by large resource-deployment differences can be alleviated. Many scholars note that newer firms usually have a lower level of structural complexity, which means a more direct connection between employees' efforts and the firms' outputs (Kotha et al. 2011). This so-called causal clarity constitutes the prerequisite for learning and imitation to occur in alliances, and the need of using acquisitions to overcome inimitability becomes weaker. Besides, firms develop their capabilities under a sequence of historical circumstances, and their capabilities are generally embedded within the social fabric of the firm. A shorter corporate history thus makes it less complicated for other companies to duplicate the competencies.

In sum, younger candidates relative to the focal firms can mitigate concerns over resource immobility and inimitability, and thus increase the likelihood of choosing an alliance over an acquisition.

H1b: The younger the candidate is relative to the focal firm, the more likely that a greater perceived interfirm difference in resource deployment is associated with the choice of an alliance over an acquisition.

\subsection{Marketing praxis and industry segment}

\subsubsection{Effects of perceived differences in marketing praxis}

Marketing praxis is a set of actions that firms undertake to sell products or services. It involves determining what products or services to offer, which customer segment(s) to target, how to reach the potential consumers, and what pricing position to maintain vis-à-vis competitors' offerings (Coviello et al. 2000). Larger interfirm differences in marketing praxis denote that firms operate in distinct competitive landscapes, and thus possess differing market expertise; in contrast, firms are very likely to be more direct competitors if their marketing praxes are similar.

Being direct competitors makes it particularly critical for each firm to protect its own market information and marketing plans from leaking to the other. This leakage issue 
is exacerbated in alliances that generate substantial economic conflicts in overlapping territories during the period of partnership (Abdi, Aulakh 2017), yet do not exist in acquisitions that reduce competition in the market.

Meanwhile, due to the fear of revealing market knowledge to rivals, allying with direct competitors usually creates shallow cooperation within a limited scope (Oxley, Sampson 2004). Further, when partners are direct competitors, it approximates a zero-sum game where a firm's financial performance is subject to its ability to position its strengths against rivals' weaknesses, and knowledge gained from the alliance would be applied by each partner in the same competitive arena (Holloway, Parmigiani 2016). As such, the payoff from misbehavior in the alliance is particularly high, which would stimulate greater opportunism in the partnership.

All of the above reasons lead to the preference for acquisitions when partnering firms are more similar in their marketing praxes, but the selection of alliances when they have greater marketing-praxis differences.

H2a: Other things being equal, a greater perceived interfirm difference in marketing praxis is associated with the choice of an alliance over an acquisition.

\subsubsection{Moderation of industry segments}

Firms in high-tech sectors are required to invest heavily in R\&D for developing innovative technologies as the source of their competitiveness (Czarnitzki, Thorwarth 2012). Competing in a high-tech industry confronts firms with a more dynamic environment that creates high levels of uncertainty and makes technologies obsolete more rapidly. In comparison, low-tech industrial environments are relatively stable and have longer product life cycles, which enable firms to pursue refinement of existing technologies (Hagedoorn, Duysters 2002).

Prior studies have noted that frequent changes in market conditions are associated with a disproportionate preference for a more flexible organizational form, such as alliances (e.g. Lioukas et al. 2016). This is because new knowledge expires quickly and nimble strategic actions are needed for firms to survive in high-tech sectors. Timely learning from partners through a loosely organizational, collaborative form appears more appropriate than pursuing formal control in acquisitions, which involve complex integration processes. The rapid obsolescence of technologies and shorter product life cycles in high-tech industries accentuate the problem of lengthy integration in acquisitions, which would create windows for rivals to catch up.

By contrast, in low-tech markets the governance decision tends to be the opposite for partners with more distinct marketing praxes. Less volatile environments in low-tech markets exacerbate the concern about leaking proprietary market knowledge to alliance partners from other areas, due to great potential of creating future competitors who gain more from the appropriation in the slow-moving setting. However, less dynamic business environments enable acquirers to better detect the intentions and value of candidates, and allow a longer grace period for acquirers to deal with integration before new factors emerge (Hagedoorn, Duysters 2002). 
H2b: In a high-tech (low-tech) sector, a greater perceived interfirm difference in marketing praxis is associated with the choice of an alliance (acquisition) over an acquisition (alliance).

\subsection{Human resource management and interfirm governance experience}

\subsubsection{Effects of perceived differences in human resource management}

Human resource (HR) management refers to the art of exercising authority, strengthening the bonds among employees based on a common platform, and motivating them to work together as a unified unit (Som 2003). HR management style is linked to organizational culture, which is the collective programming of the mind that distinguishes the members of one group of people from another (Datta 1991). As such, individuals at different organizations are inclined to form their own work approaches and develop their unique leadership practices. When there are large interfirm differences in HR management, more conflicts are likely to occur between firms.

The issue of significant HR management differences is more problematic in acquisitions than in alliances. Acquisitions entail integration of workforces from acquired and acquiring firms that may have diametrically opposed managerial styles (Wang et al. 2016). Research on trust thinks that clashes among members belonging to different groups stem from their divergent managerial schemes, where perceptual biases build and mutual trust erodes (Kramer 1999). As anecdotal evidence shows that employees in the acquired firms often react unfavorably to the change in ownership (Guerrero 2008), a lack of trust between the acquired and the acquiring parties due to significant HR management differences will make those employees feel uncertain with regard to their career patterns, mobility, and development. Such problems pose substantial obstacles in integration and prevent realization of the acquisition's benefits.

In comparison, alliances are a more appropriate governance choice, since higher flexibility allowed in such collaborations offers more room and time to deal with the tension, distrust, and hostility due to significant HR management differences between partners (Hoehn-Weiss et al. 2017). Thus, alliances appear to provide a buffer zone for smoothing out interfirm managerial collisions.

H3a: Other things being equal, a greater perceived interfirm difference in HR management is associated with the choice of an alliance over an acquisition.

\subsubsection{Moderation of prior interfirm governance experience}

When facing candidates with different HR management styles, firms possessing more interfirm governance experience of alliances and acquisitions are likely to have a stronger preference for acquisitions over alliances. First, after firms have made a considerable number of acquisitions, they tend to develop routines that can serve as a blueprint for and can be replicated on new acquisitive activities. These routines contain preferred approaches, speeds, and sequences of integration. Because routines frequently embody and exert inertial forces, prior experience increases the likelihood of subsequent acquisitions (Zollo 2009). 
Second, insofar as alliance experience is concerned, it is also conducive to undertaking more acquisitions. Forming alliances involves partner selection, contract negotiation and enforcement, and interfirm coordination (Krishnan et al. 2016). These procedures are similar to those in acquisitions, which involve target selection, negotiation and stipulation of acquisitive deals, and interfirm integration. The similarities between alliance and acquisition practices give firms opportunities to accumulate relevant knowledge about conducting acquisitions.

H3b: The more prior interfirm governance experience that the focal firm possesses, the more likely that a greater perceived interfirm difference in HR management is associated with the choice of an acquisition over an alliance.

\section{Methods}

\subsection{Data and sample}

We tested our hypotheses on a sample of alliances and acquisitions made by Taiwanese manufacturers. We chose this context for four reasons. First, Taiwanese firms have engaged heavily in allying with or acquiring other firms so as to gain strong footholds in global marketplaces. Second, firms in the manufacturing industry have intensive involvement in alliances and acquisitions. Third, limiting observations to the manufacturers from one country helps minimize home-country and industry effects. Fourth, our focus on alliances or acquisitions taking place between high-tech firms or between low-tech firms allows us to examine how the ally-versus-acquire choice varies across the two industries.

We collected the data in 2013 through a questionnaire mail survey. A list of alliances and acquisitions conducted during 2010 and 2012 was first compiled from the Securities Data Company (SDC) database. The focal firm in an alliance is the Taiwanese participant if it is an international alliance and the dominant partner (holding more equity for equitybased alliances, or initiating the cooperation for non-equity ones) in a domestic alliance, while the focal firm in an acquisition is the Taiwanese acquirer. The above sampling frame yielded 345 alliances and 360 acquisitions.

Our key informants are senior executives with titles such as general managers or chief executive officers, and all were involved in the alliances or acquisitions. The types of industry that their firms operated in comprise (electronics, communication, and computer) equipment manufacturing, food processing, textile, and metal fabrication. On average, the age of their firms is around 30 years up to the event date, and their size approximates 10,000 employees.

The development of our questionnaire was guided by theoretical considerations, previous literature, and consultation with experts. We first developed the questionnaire in English and then translated it into Chinese. To ensure item equivalence in both languages, we back translated from Chinese to English, and compared the two versions. The scales were reverse-coded where appropriate to reduce social desirability bias. We pre-tested our Chinese questionnaire with 20 senior managers and then refined items. 
After the initial mailing and two waves of reminders, we received a total of 141 completed and usable surveys for a $20 \%$ response rate, which is comparable to that of other recent studies conducted in Taiwan (Contractor et al. 2005). Table 2 summarizes respondent profiles by governance choices. To check nonresponse bias, we performed t-tests to compare the participants on the initial list of 345 alliances and 360 acquisitions with those who returned our surveys using information available from secondary sources. The results of insignificant differences suggest no nonresponse bias.

Table 2. Respondent firm profiles $(\mathrm{N}=141)$

\begin{tabular}{lcc}
\hline & Acquisition $(\mathrm{N}=63)$ & Alliance $(\mathrm{N}=78)$ \\
\hline Resource deployment differences (mean value) & 5.42 & 4.55 \\
\hline HR management differences (mean value) & 4.39 & 5.05 \\
\hline Marketing praxis differences (mean value) & 4.01 & 3.58 \\
\hline Institutional distance (mean value) & 1.65 & 1.45 \\
\hline Relative firm age (Log transformed mean value) & 1.09 & 3.08 \\
\hline Prior governance experience (mean value) & 2.83 & 2.17 \\
\hline Industry segments & & 35 \\
High-tech (number of firms) & 48 & 43 \\
Low-tech (number of firms) & 15 &
\end{tabular}

\subsection{Dependent variable}

Governance mode choice, alliances versus acquisitions, was captured by a dummy variable in which 1 indicates an acquisition and 0 represents an alliance. Consistent with the definition discussed in prior studies (Carayannopoulos, Auster 2010), our acquisitive cases all have a controlling interest of over $50 \%$, and our alliance sample includes both non-equity and equity-based forms of partnership.

\subsection{Independent variables}

Based on our literature review, resource-deployment differences were assessed on four critical organizational resources (Tseng et al. 2007). Following Homburg and Bucerius (2006), we measured marketing-praxis differences with five items concerning target customers, product or service features, distribution channels, and pricing positioning. Adapted from Datta (1991), we used five items to gauge HR-management differences in output- /process-oriented, bureaucratic/unbureaucratic, punishment/reward, hierarchical/ egalitarian, and authoritative/participative dimensions. Table 3 lists these items.

\subsection{Moderators}

We computed relative firm age by subtracting the age of a candidate firm from the age of the focal firm. A greater value indicates a younger candidate relative to the focal firm. The alliances or acquisitions participated in by pairs of firms operating in high-tech industries were coded " 1 " and " 0 " for the pairs in low-tech industries. We distinguished between low-and high-tech segments based on the definitions given by the US Department of Labor (Hecker 2005) and the guidelines suggested by Kile and 
Phillips (2009). Focal firms' prior interfirm governance experience was gauged by the cumulative number of alliances and acquisitions that the focal firms had undertaken since their founding up to the year of the focal events.

\subsection{Control variables}

We controlled for four variables influential to governance mode choice in previous studies (Yang et al. 2010; Zhou et al. 2016). Firm size difference was measured by calculating the difference between two firms in the number of employees. We adopted the composite index introduced by Kogut and Singh (1988) to assess institutional distance between the home country of a candidate and that of a focal firm. Ex-ante performance was gauged by focal firms' satisfaction with market share and profitability before the focal event ( $1=$ strongly dissatisfied to $7=$ strongly satisfied). Risk perception asks respondents about their assessment of creating potential competitors, leaking proprietary assets, and losing competitive advantages $(1=$ strongly disagree to $7=$ strongly agree).

Table 3. Survey items for cognitive interfirm differences

\begin{tabular}{|c|c|c|c|}
\hline Constructs & $\begin{array}{l}\text { Factor } \\
\text { loadings }\end{array}$ & $\begin{array}{l}\text { Average } \\
\text { variance } \\
\text { extracted }\end{array}$ & $\begin{array}{l}\text { Construct } \\
\text { reliability }\end{array}$ \\
\hline $\begin{array}{l}\text { Interfirm differences in resource deployment (anchored on a } \\
\text { seven-point Likert scale, } 1=\text { strongly similar to } 7=\text { strongly } \\
\text { different) }\end{array}$ & & 0.60 & 0.86 \\
\hline \multicolumn{4}{|l|}{ Compare your firm with the candidate firm: } \\
\hline Allocate resources to boost $R \& D$ intensity & 0.81 & & \\
\hline Allocate resources to enhance manufacturing efficiency & 0.79 & & \\
\hline Allocate resources to improve financial position & 0.69 & & \\
\hline Allocate resources to cultivate human talents & 0.81 & & \\
\hline $\begin{array}{l}\text { Interfirm differences in marketing praxis (anchored on a seven- } \\
\text { point Likert scale, } 1=\text { strongly agree to } 7=\text { strongly disagree) }\end{array}$ & & 0.57 & 0.87 \\
\hline \multicolumn{4}{|l|}{ Compare your firm with the candidate firm: } \\
\hline Target at the same groups of customers & 0.68 & & \\
\hline Offer products/services made with the same technology & 0.78 & & \\
\hline Offer products/services identical in quality & 0.77 & & \\
\hline Sell products/services through the same channels & 0.73 & & \\
\hline Have the same pricing positioning & 0.81 & & \\
\hline $\begin{array}{l}\text { Interfirm differences in HR management (anchored on a seven- } \\
\text { point Likert scale, } 1=\text { strongly similar to } 7=\text { strongly different) }\end{array}$ & & 0.63 & 0.87 \\
\hline \multicolumn{4}{|l|}{ Compare your firm and the candidate firm: } \\
\hline Encourage employees to try new and better ways of doing a job & 0.72 & & \\
\hline Define each employee's duty clearly & 0.75 & & \\
\hline $\begin{array}{l}\text { Give more praise and recognition than punishments to } \\
\text { motivate employees }\end{array}$ & 0.92 & & \\
\hline Treat employees equally and as family members & 0.78 & & \\
\hline \multicolumn{4}{|l|}{$\begin{array}{l}\text { Encourage employees to actively participate in all corporate } \\
\text { activities and events* }\end{array}$} \\
\hline Fit Indices: $\chi^{2}=121.60$, d.f. $=62, \mathrm{p}<.001 ; \mathrm{NNFI}=.96 ; \mathrm{CFI}=$ & RM & $=.07$ & \\
\hline
\end{tabular}

Note: *Item was dropped during the measure validation process. 


\subsection{Measure validation}

Confirmatory factor analyses assessed the convergent and discriminant validity of all variables measured on reflective scales (Gerbing, Anderson 1988). The results indicate a reasonable fit for the model $\left(\chi^{2}=121.60\right.$, d.f. $=62, \mathrm{p}<0.001$; NNFI $=0.96$; CFI $=$ 0.97 ; RMSEA $=0.07)$. All the indicators loaded substantively $(0.68$ or above) and significantly on their hypothesized factors $(\mathrm{p}<0.001)$. Average variance extracted ranged from 0.57 to 0.63 , and construct reliabilities from 0.86 to 0.87 (Nunnally, Bernstein 1994). With regard to evidence of discriminant validity, in all cases the average variance extracted by each factor exceeded the squared correlation between the factor pair (Fornell, Larcker 1981). Establishing discriminant validity using the average variance extracted measure also protects against the deleterious effects of multicollinearity in the presence of measurement error (Grewal et al. 2004). The confirmatory factor analysis results are shown in Table 3.

One concern with survey measures is the presence of common method variance. We used the Harman one-factor test to examine this issue (Podsakoff, Organ 1986), an approach routinely used in the literature (Newbert 2008). The factor analysis of the variables used in the regression models did not yield one single factor and the first factor did not account for the majority of the variance (only 18.5\%), indicating no serious common method variance.

\section{Results}

Table 4 reports the descriptive statistics and the correlation matrix. Our binary dependent variable dictates us to use binomial logistic regression in which positive coefficients signify that independent variables or interaction terms increase the probability of choosing acquisitions over alliances. To minimize multicollinearity, we mean centered our constructs before creating interaction terms. Table 5 shows the results of our hypotheses testing. Model I reports the results with only the control variables, Models II, III, and IV with the addition of three sets of main effects and interactions, and Model V the full model. The full model has much better fitness (Chi-square $=63.27, \mathrm{p}<0.001$; Cox \& Snell R-square $=0.362$ ) than other models, showing the adequate explanatory power of our conceptual framework.

H1a postulated that an acquisition is more preferable than an alliance for larger resource-deployment differences, and the results support the hypothesis $(b=0.450, p$ $<0.01)$. Taking into account the moderating effect of relative firm age, alliances are more favorable than acquisitions for a relatively younger target $(b=-0.025, p<0.001)$, showing support for H1b. H2a proposed that greater marketing-praxis differences will favor an alliance more than an acquisition, and we found support for this $(b=-0.400$, $\mathrm{p}<0.10$ ). Our results do not support $\mathrm{H} 2 \mathrm{~b}$ that firms in high-tech sectors tend to choose alliances, while those in low-tech sectors acquisitions, in order to manage marketingpraxis differences $(b=0.420, p>0.10)$. H3a posited that increased HR-management differences make alliances more favorable than acquisitions, and we found support for this $(b=-0.631, p<0.01)$. We also obtained support for H3b that greater interfirm governance experience strengthens the possibility of using acquisitions rather than alliances for tackling large interfirm HR-management differences $(b=1.101, p<0.10)$. 
Table 4. Descriptive statistics and correlations

\begin{tabular}{|c|c|c|c|c|c|c|c|c|c|c|}
\hline & 1 & 2 & 3 & 4 & 5 & 6 & 7 & 8 & 9 & 10 \\
\hline $\begin{array}{l}\text { 1. Governance } \\
\text { Mode }\end{array}$ & 1.00 & & & & & & & & & \\
\hline $\begin{array}{l}\text { 2. Resource } \\
\text { Deployment } \\
\text { Differences }\end{array}$ & $0.30^{*}$ & 1.00 & & & & & & & & \\
\hline $\begin{array}{l}\text { 3. HR } \\
\text { Management } \\
\text { Differences }\end{array}$ & -0.25 & -0.05 & 1.00 & & & & & & & \\
\hline $\begin{array}{l}\text { 4. Marketing } \\
\text { Praxis } \\
\text { Differences }\end{array}$ & -0.13 & $-0.28^{*}$ & -0.05 & 1.00 & & & & & & \\
\hline $\begin{array}{l}\text { 5. Relative } \\
\text { Firm Age }\end{array}$ & 0.12 & $0.22 *$ & -0.08 & -0.04 & 1.00 & & & & & \\
\hline $\begin{array}{l}\text { 6. Interfirm } \\
\text { Governance } \\
\text { Experience }\end{array}$ & 0.13 & 0.16 & 0.01 & $-0.28^{*}$ & $0.19^{*}$ & 1.00 & & & & \\
\hline $\begin{array}{l}\text { 7. Industry } \\
\text { Segments }\end{array}$ & $0.32 *$ & 0.12 & 0.02 & -0.12 & 0.08 & 0.10 & 1.00 & & & \\
\hline $\begin{array}{l}\text { 8. Institutional } \\
\text { Distance }\end{array}$ & 0.04 & -0.13 & 0.04 & -0.11 & -0.11 & 0.15 & $0.19 *$ & 1.00 & & \\
\hline $\begin{array}{l}\text { 9. Ex-ante } \\
\text { Performance }\end{array}$ & -0.03 & 0.06 & $0.27^{*}$ & $0.23^{*}$ & -0.09 & -0.01 & 0.04 & 0.05 & 1.00 & \\
\hline $\begin{array}{l}\text { 10. Risk } \\
\text { Perception }\end{array}$ & 0.13 & 0.07 & -0.07 & 0.11 & 0.09 & 0.10 & 0.04 & -0.09 & 0.12 & 1.00 \\
\hline Mean & 0.45 & 4.94 & 4.75 & 3.77 & 6.14 & 2.64 & 0.59 & 1.54 & 5.10 & 3.59 \\
\hline $\begin{array}{l}\text { Standard } \\
\text { Deviation }\end{array}$ & 0.50 & 1.45 & 1.32 & 1.62 & 29.45 & 0.30 & 0.49 & 2.67 & 1.43 & 1.37 \\
\hline
\end{tabular}

Note: $* p<0.05$. 
Table 5. Binomial logistic regression results (acquisition $=1$ and alliance $=0$ )

\begin{tabular}{|c|c|c|c|c|c|}
\hline & Model I & Model II & Model III & Model IV & Model V \\
\hline Resource Deployment & & $0.545^{* * *}$ & & & $0.450 * *$ \\
\hline Differences (H1a: +) & & $(0.154)$ & & & $(0.181)$ \\
\hline $\begin{array}{l}\text { Resource Deployment } \\
\text { Differences x Relative Firm } \\
\text { Age (H1b: }-)\end{array}$ & & $\begin{array}{c}-0.019 * * \\
(0.006)\end{array}$ & & & $\begin{array}{c}-0.025 * * * \\
(0.007)\end{array}$ \\
\hline $\begin{array}{l}\text { Marketing Praxis Differences } \\
(\mathrm{H} 2 \mathrm{a}:-)\end{array}$ & & & $\begin{array}{c}-0.614^{* *} \\
(0.219)\end{array}$ & & $\begin{array}{l}-0.400^{+} \\
(0.250)\end{array}$ \\
\hline $\begin{array}{l}\text { Marketing Praxis Differences } \\
\text { x Industry segments (H2b: -) }\end{array}$ & & & $\begin{array}{l}0.708^{* *} \\
(0.263)\end{array}$ & & $\begin{array}{c}0.420 \\
(0.320)\end{array}$ \\
\hline $\begin{array}{l}\text { HR Management Differences } \\
(\text { H3a: -) }\end{array}$ & & & & $\begin{array}{c}-0.404 * * \\
(0.147)\end{array}$ & $\begin{array}{c}-0.631^{* *} \\
(0.204)\end{array}$ \\
\hline $\begin{array}{l}\text { HR Management Differences } \\
\text { x Interfirm Governance } \\
\text { Experience }(\mathrm{H} 3 \mathrm{~b}:+)\end{array}$ & & & & $\begin{array}{c}0.727 \\
(0.574)\end{array}$ & $\begin{array}{l}1.101^{+} \\
(0.762)\end{array}$ \\
\hline Relative Firm Age & & $\begin{array}{l}0.014^{+} \\
(0.009)\end{array}$ & & & $\begin{array}{l}0.020^{+} \\
(0.011)\end{array}$ \\
\hline Industry Segments & & & $\begin{array}{c}4.111 * * * \\
(1.145)\end{array}$ & & $\begin{array}{l}3.394 * * \\
(1.361)\end{array}$ \\
\hline $\begin{array}{l}\text { Interfirm Governance } \\
\text { Experience }\end{array}$ & & & & $\begin{array}{c}0.529 \\
(0.627)\end{array}$ & $\begin{array}{c}0.050 \\
(0.833)\end{array}$ \\
\hline Firm Size Difference & $\begin{array}{c}0.001 \\
(0.001)\end{array}$ & $\begin{array}{c}0.001 \\
(0.001)\end{array}$ & $\begin{array}{c}0.001 \\
(0.001)\end{array}$ & $\begin{array}{c}0.001 \\
(0.001)\end{array}$ & $\begin{array}{c}0.001 \\
(0.001)\end{array}$ \\
\hline Institutional Distance & $\begin{array}{c}0.040 \\
(0.064)\end{array}$ & $\begin{array}{c}0.059 \\
(0.075)\end{array}$ & $\begin{array}{l}-0.016 \\
(0.069)\end{array}$ & $\begin{array}{c}0.024 \\
(0.068)\end{array}$ & $\begin{array}{l}-0.005 \\
(0.086)\end{array}$ \\
\hline Ex-ante Performance & $\begin{array}{c}0.241 \\
(0.180)\end{array}$ & $\begin{array}{l}-0.114 \\
(0.193)\end{array}$ & $\begin{array}{l}-0.255 \\
(0.199)\end{array}$ & $\begin{array}{c}0.043 \\
(0.188)\end{array}$ & $\begin{array}{c}0.018 \\
(0.240)\end{array}$ \\
\hline Risk Perception & $\begin{array}{l}-0.312 \\
(0.201)\end{array}$ & $\begin{array}{l}0.347^{+} \\
(0.203)\end{array}$ & $\begin{array}{c}0.110 \\
(0.199)\end{array}$ & $\begin{array}{c}0.222 \\
(0.191)\end{array}$ & $\begin{array}{c}0.305 \\
(0.248)\end{array}$ \\
\hline Cox \& Snell R ${ }^{2}$ & 0.033 & 0.202 & 0.178 & 0.105 & 0.362 \\
\hline Chi-square & 4.69 & $31.83 * * *$ & $27.63 * * *$ & $15.65^{*}$ & $63.27 * * *$ \\
\hline
\end{tabular}

Notes: ${ }^{+} p<0.10,{ }^{*} p<0.05,{ }^{* *} p<0.01,{ }^{* * *} p<0.001$; standard errors are in the parentheses.

We plotted the patterns of significant moderating effects. As Figure 2 shows, the propensity to choose alliances increases when a candidate firm is relatively younger and there is a rising interfirm resource-deployment difference. By contrast, in the case where a candidate firm is older, the increasing interfirm resource-deployment difference is more likely to lead to the choice of acquisitions. As demonstrated in Figure 3, the probability of choosing acquisitions is higher for firms with more interfirm governance experience when there is a large interfirm HR-management difference. 


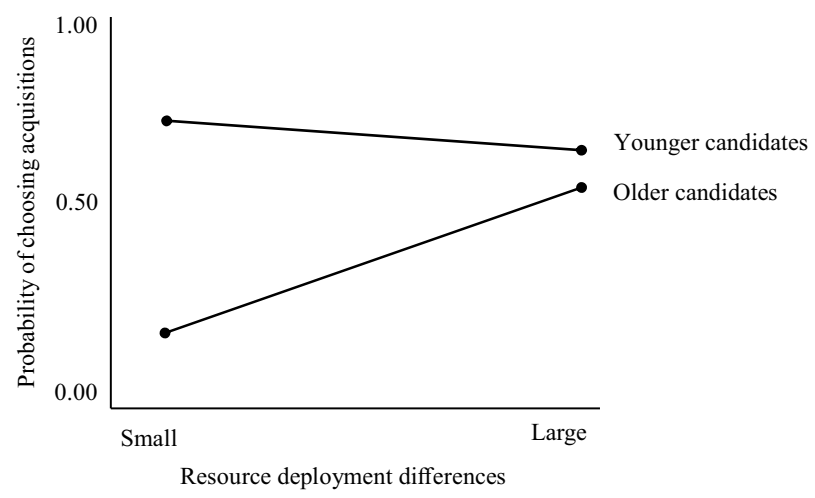

Fig. 2. The moderating effect of relative firm age on the relationship between resource deployment differences and the ally-versus-acquire choice

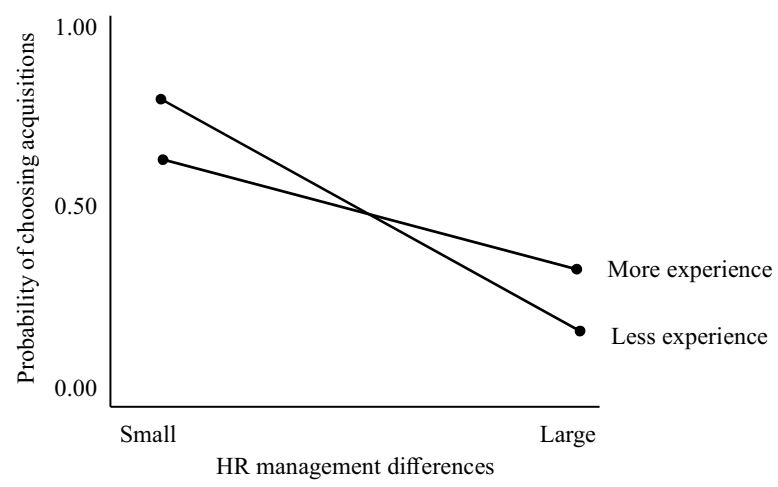

Fig. 3. The moderating effect of interfirm governance experience on the relationship between HR management differences and the ally-versus-acquire choice

\section{Conclusions}

This study makes several important contributions. First, subjective assessments have been underexplored in the ally-versus-acquire choice research. This study analyzes how managers' perceptions of interfirm differences affect this decision, and further recognizes the importance of combining subjective and objective evaluations in this decision. Second, as resource deployment concerns the development of proprietary knowledge, this study suggests using acquisitions to tackle this interfirm difference and to obtain desired knowhow. In comparison, as to managerial differences in such areas as marketing praxis and HR management, alliances are more suitable to buffer interfirm conflicts. Third, the significant moderating role of relative firm age supports the resource-based view that assets with a history-dependent nature are inimitable and have high causal ambiguity to outsiders, rendering acquisitions more efficient to obtain the assets held by older targets. Besides, the salient moderation of interfirm governance experience resonates with the learning and spillover effects discussed in the learning literature.

The present study has some limitations that, at the same time, represent directions for future research. To begin with, our sample consists of acquisitions and alliances 
conducted by Taiwanese firms in high- and low-tech industrial sectors. Although we believe that this sampling frame provides a suitable platform for testing our conceptual framework, caution should be exercised in generalizing our results to other business or national settings. Second, this study aims to capture managers' perception of interfirm differences and have carefully developed measurement. Future research may think to also devise objective measures for our constructs, and compare the effects of the two types of appraisals. Last, our identification of moderators is based on the theoretical argument central to key features of each interfirm difference. Future research can extend our conceptualization by considering other moderators.

\section{References}

Abdi, M.; Aulakh, P. S. 2017. Locus of uncertainty and the relationship between contractual and relational governance in cross-border interfirm relationships, Journal of Management 43(3): 771-803. https://doi.org/10.1177/0149206314541152

Alba, J. W.; Hasher, L. 1983. Is memory schematic?, Psychological Bulletin 93(2): 203-231. https://doi.org/10.1037/0033-2909.93.2.203

Barney, J. 1991. Firm resources and sustained competitive advantage, Journal of Management 17(1): 99-120. https://doi.org/10.1177/014920639101700108

Bauer, F.; Matzler, K. 2014. Antecedents of M\&A success: the role of strategic complementarity, cultural fit, and degree and speed of integration, Strategic Management Journal 35(2): 269-291. https://doi.org/10.1002/smj.2091

Carayannopoulos, S.; Auster, E. R. 2010. External knowledge sourcing in biotechnology through acquisition versus alliance: a KBV approach, Research Policy 39(2): 254-267.

https://doi.org/10.1016/j.respol.2009.12.005

Contractor, F. J.; Hsu, C.-C.; Kundu, S. K. 2005. Explaining export performance: a comparative study of international new ventures in Indian and Taiwanese software industry, Management International Review 45: 83-110.

Coviello, N. E.; Brodie, R. J.; Munro, H. J. 2000. An investigation of marketing practice by firm size, Journal of Business Venturing 15(5-6): 523-545.

https://doi.org/10.1016/S0883-9026(98)00035-4

Cuypers, I. R. P.; Cuypers, Y.; Martin, X. 2017. When the target may know better: effects of experience and information asymmetries on value from mergers and acquisitions, Strategic Management Journal 38(3): 609-625. https://doi.org/10.1002/smj.2502

Czarnitzki, D.; Thorwarth, S. 2012. Productivity effects of basic research in low-tech and hightech industries, Research Policy 41(9): 1555-1564. https://doi.org/10.1016/j.respol.2012.04.009

Datta, D. K. 1991. Organizational fit and acquisition performance: effects of post-acquisition integration, Strategic Management Journal 12(4): 281-297.

https://doi.org/10.1002/smj.4250120404

Ellis, K. M.; Reus, T. H.; Lamont, B. T.; Ranft, A. L. 2011. Transfer effects in large acquisitions: how size-specific experience matters, Academy of Management Journal 54(6): 1261-1276. https://doi.org/10.5465/amj.2009.0122

Fonti, F.; Maoret, M.; Whitbred, R. 2017. Free-riding in multi-party alliances: the role of perceived alliance effectiveness and peers' collaboration in a research consortium, Strategic Management Journal 38(2): 363-383. https://doi.org/10.1002/smj.2470

Fornell, C.; Larcker, D. F. 1981. Evaluating structural equation models with unobservable variables and measurement error, Journal of Marketing Research 18(1): 39-50.

https://doi.org/10.2307/3151312 
Gerbing, D. W.; Anderson, J. C. 1988. An updated paradigm for scale development incorporating unidimensionality and its assessment, Journal of Marketing Research 25(2): 186-192.

https://doi.org/10.2307/3172650

Ginsberg, A. 1994. Minding the competition: from mapping to mastery, Strategic Management Journal 15(S1): 153-174. https://doi.org/10.1002/smj.4250150911

Glendening, M.; Khurana, I. K.; Wang, W. 2016. The market for corporate control and dividend policies: cross-country evidence from M\&A laws, Journal of International Business Studies 47(9): 1106-1134. https://doi.org/10.1057/s41267-016-0028-x

Graffin, S. D.; Haleblian, J.; Kiley, J. T. 2016. Ready, AIM, acquire: impression offsetting and acquisitions, Academy of Management Journal 59(1): 232-252.

https://doi.org/10.5465/amj.2013.0288

Grewal, R.; Cote, J. A.; Baumgartner, H. 2004. Multicollinearity and measurement error in structural equation models: implications for theory testing, Marketing Science 23(4): 519-529. https://doi.org/10.1287/mksc. 1040.0070

Guerrero, S. 2008. Changes in employees' attitudes at work following an acquisition: a comparative study by acquisition type, Human Resource Management Journal 18(3): 216-236. https://doi.org/10.1111/j.1748-8583.2008.00068.x

Hagedoorn, J.; Duysters, G. 2002. External sources of innovative capabilities: the preference for strategic alliances or mergers and acquisitions, Journal of Management Studies 39(2): 167-188. https://doi.org/10.1111/1467-6486.00287

Hecker, D. E. 2005. High-technology employment: a NAICS-based update, Monthly Labor Review 128(7): 57-72.

Hoehn-Weiss, M. N.; Karim, S.; Lee, C.-H. 2017. Examining alliance portfolios beyond the dyads: the relevancy of redundancy and nonuniformity across and between partners, Organization Science 28(1): 56-73. https://doi.org/10.1287/orsc.2017.1108

Holloway, S. S.; Parmigiani, A. 2016. Friends and profits don't mix: the performance implications of repeated partnerships, Academy of Management Journal 59(2): 460-478.

https://doi.org/10.5465/amj.2013.0581

Homburg, C.; Bucerius, M. 2006. Is speed of integration really a success factor of mergers and acquisitions? An analysis of the role of internal and external relatedness, Strategic Management Journal 27(4): 347-367. https://doi.org/10.1002/smj.520

Kile, C. O.; Phillips, M. E. 2009. Using industry classification codes to sample high-technology firms: analysis and recommendations, Journal of Accounting, Auditing \& Finance 24(1): 35-58. https://doi.org/10.1177/0148558X0902400104

Kogut, B.; Singh, H. 1988. The effect of national culture on the choice of entry mode, Journal of International Business Studies 19(3): 411-432. https://doi.org/10.1057/palgrave.jibs.8490394

Kor, Y.; Mahoney, J. T. 2005. How dynamics, management, and governance of resource deployments influence firm-level performance, Strategic Management Journal 26(5): 489-496. https://doi.org/10.1002/smj.459

Kotha, R.; Zheng, Y.; George, G. 2011. Entry into new niches: the effects of firm age and the expansion of technological capabilities on innovative output and impact, Strategic Management Journal 32(9): 1011-1024. https://doi.org/10.1002/smj.915

Kramer, R. M. 1999. Trust and distrust in organizations: emerging perspectives, enduring questions, Annual Review of Psychology 50: 569-598. https://doi.org/10.1146/annurev.psych.50.1.569

Krishnan, R.; Geyskens, I.; Steenkamp, J. E. M. 2016. The effectiveness of contractual and trustbased governance in strategic alliances under behavioral and environmental uncertainty, Strategic Management Journal 37(12): 2521-2542. https://doi.org/10.1002/smj.2469

Lavie, D.; Haunschild, P.; Khanna, P. 2012. Organizational differences, relational mechanisms, and alliance performance, Strategic Management Journal 33(13): 1453-1479.

https://doi.org/10.1002/smj.1987 
Lioukas, C. S.; Reuer, J. J.; Zollo, M. 2016. Effects of information technology capabilities on strategic alliances: implications for the resource-based view, Journal of Management Studies 53(2): 161-183. https://doi.org/10.1111/joms.12179

Madsen, P. M.; Desai, V. 2010. Failing to learn? The effects of failure and success on organizational learning in the global orbital launch vehicle industry, Academy of Management Journal 53(3): 451-476. https://doi.org/10.5465/AMJ.2010.51467631

Newbert, S. L. 2008. Value, rareness, competitive advantage, and performance: a conceptual-level empirical investigation of the resource-based view of the firm, Strategic Management Journal 29(7): 745-768. https://doi.org/10.1002/smj.686

Nunnally, J. C.; Bernstein, I. H. 1994. Psychometric theory. New York: McGraw-Hill.

Oxley, J. E.; Sampson, R. C. 2004. The scope and governance of international R\&D alliances, Strategic Management Journal 25(8-9): 723-749. https://doi.org/10.1002/smj.391

Podsakoff, P. M.; Organ, D. W. 1986. Self-reports in organizational research: problems and prospects, Journal of Management 12(4): 531-544. https://doi.org/10.1177/014920638601200408

Reuer, J. J.; Devarakonda, S. V. 2016. Mechanism of hybrid governance: administrative committees in non-equity alliances, Academy of Management Journal 59(2): 510-533.

https://doi.org/10.5465/amj.2012.0098

Som, A. 2003. Redesigning the human resources function at Lafarge, Human Resource Management 42(3): 271-288. https://doi.org/10.1002/hrm.10085

Tseng, C.-H.; Tansuhaj, P.; Hallagan, W.; McCullough, J. 2007. Effects of firm resources on growth in multinationality, Journal of International Business Studies 38(6): 961-974.

https://doi.org/10.1057/palgrave.jibs.8400305

Wang, L.; Zajac, E. J. 2007. Alliance or acquisition? A dyadic perspective on interfirm resource combinations, Strategic Management Journal 28(13): 1291-1317. https://doi.org/10.1002/smj.638

Wang, H.; Zhao, S.; He, J. 2016. Increase in takeover protection and firm knowledge accumulation strategy, Strategic Management Journal 37(12): 1453-1479.

https://doi.org/10.1002/smj.2443

Wassmer, U.; Li, S.; Madhok, A. 2017. Resource ambidexterity through alliance portfolios and firm performance, Strategic Management Journal 38(2): 2393-2412.

https://doi.org/10.1002/smj.2488

Wernerfelt, B. 1984. A resource-based view of the firm, Strategic Management Journal 5(2): 171-180. https://doi.org/10.1002/smj.4250050207

Winter, S. G. 2003. Understanding dynamic capabilities, Strategic Management Journal 24(10): 991-995. https://doi.org/10.1002/smj.318

Yang, H.; Lin, Z.; Lin, Y. 2010. A multilevel framework of firm boundaries: firm characteristics, dyadic differences, and network attributes, Strategic Management Journal 31(3): 237-261. https://doi.org/10.1002/smj.815

Zhou, C.; Xie, J.; Wang, Q. 2016. Failure to complete cross-border M\&As: "to" vs. "from" emerging markets, Journal of International Business Studies 47(9): 1077-1105.

https://doi.org/10.1057/s41267-016-0027-y

Zollo, M. 2009. Superstitious learning with rare strategic decisions: theory and evidence from corporate acquisitions, Organization Science 20(5): 894-908. https://doi.org/10.1287/orsc.1090.0459

Chiung-Hui TSENG is Associate Professor at National Cheng Kung University in Taiwan. She received her $\mathrm{PhD}$ in International Business from Washington State University in the US. Her research interests are alliances and acquisitions, foreign entry strategy, and firm diversification. Her publications have appeared in several SSCI journals, including Canadian Journal of Administrative Sciences, International Business Review, Journal of Business Economics and Management, Journal of International Business Studies, among others. 